\title{
Opsonic Activity of Cord Blood Sera against Various Species of Microorganism
}

\author{
LASZLO MÁRÓDI,* PETER C. J. LEIJH, ARMANDO BRAAT, MOHAMED R. DAHA, AND \\ RALPH VAN FURTH \\ Department of Infectious Diseases [L. M., P. C. J. L., A. B., R. v. F.] and Nephrology [M. R. D.], \\ University Hospital, Leiden, The Netherlands
}

\begin{abstract}
The results of the present study on the opsonic activity of cord blood serum against various microorganisms (Staphylococcus aureus, Escherichia coli, and group B streptococci) show that the activity of cord blood serum in promoting IgG-mediated ingestion is equal to that of sera of healthy adults. This implies that IgG concentrations, as assessed by immunochemical methods, in cord blood and adult sera represent functionally similar IgG activities. Ingestion of microorganisms involving complement-dependent opsonization was found to be of the same level for cord blood and adult sera, when the opsonization occurred via the classical pathway of complement activation. However, due to decreased concentrations of factors $B, P$, and $D$ in cord blood serum, optimal opsonization of microorganisms requiring the alternative pathway of complement was impaired. Taken together, these results indicate that an opsonic defect of cord blood serum affects mainly microorganisms requiring opsonization via the alternative pathway of complement. (Pediatr Res 19: 433436, 1985)
\end{abstract}

\section{Abbreviations}

HBSS, Hanks' balanced salt solution AP50, alternate pathway of complement CH50, classical pathway of complement

Interaction between serum proteins and microorganisms may lead to the generation of chemotactic factors and may promote ingestion of microorganisms by granulocytes and monocytes (14). An impairment of the functional activity of human serum caused by an antibody deficiency or a complement disorder was found to be associated with recurrent and severe infections (58).

Investigations on the functional activity of sera of newborns as a source of opsonins showed that these sera have less opsonic activity than sera from adults. Despite this general conclusion, the published data are difficult to interpret and often contradictory $(9-17)$. The main reason for these discrepancies lies in the use of different assays, different types of particles, particle size, and different serum concentrations. Concentrations of complement components important for the opsonization of various

Received July 19, 1984; accepted December 27, 1984.

Correspondence Dr. Ir. P. C. J. Leijh, Department of Infectious Diseases, University Hospital, P.O. Box 9600, 2300 RC Leiden, The Netherland.

L. M. was the recipient of a grant from the Netherlands Ministry of Education.

* Present address: Department of Pediatrics, University Medical School Debrecen, 4012 Debrecen, PF: 32 , Hungary. microorganisms in newborns were found to be relatively low compared with the levels in adults; however, normal and even elevated levels of complement proteins have also been reported (18-27).

Herein we report studies on the opsonic activity of cord-blood sera for Staphylococcus aureus, Escherichia coli, and group B streptococci as well as the concentrations of immunoglobulins and complement components in these sera.

\section{MATERIALS AND METHODS}

Sera. Five to $10 \mathrm{ml}$ cord blood were collected under aseptic conditions from the placental end of the umbilical cord of 30 healthy, full-term neonates at delivery in the Department of Obstetrics and Gynaecology of the Leiden University Hospital and the Department of Gynaecology of the Diaconessenhuis in Leiden. For the control studies use was made of blood from 40 healthy donors. Serum was prepared by clotting the blood for 1 $\mathrm{h}$ at room temperature followed by centrifugation for $20 \mathrm{~min}$ at $1200 \times g$, and was stored in aliquots at $-70^{\circ} \mathrm{C}$. Serum from cord blood of newborns will be called cord blood serum here and serum prepared from the blood of adults will be called normal adult serum. Heat-inactivated serum was prepared by heating serum for $30 \mathrm{~min}$ at $56^{\circ} \mathrm{C}$.

Determination of immunoglobulin concentrations. Concentrations of immunoglobulins (IgG, IgM, IgA) were determined in cord blood sera by immunodiffusion with anti-IgG, anti-IgM, and anti-IgA sera (Central Laboratory of The Netherlands Red Cross Blood Transfusion Service, Amsterdam), and expressed as international units. Concentrations of $\mathrm{IgG}$ subclasses were determined with sheep anti-human IgG subclass sera (Nordic, Tilburg, The Netherlands), according to Ouchterlony (28) and expressed as the maximal serum dilution giving a positive precipitation line; IgG subclass concentrations were compared with corresponding concentrations in a normal adult donor serum pool.

Determination of complement activities. The activity of the $\mathrm{CH} 50$ and AP50 activation was determined by hemolytic titration (CH50 and AP50, respectively), as described elsewhere (29, 30 ), and expressed in $\mathrm{U} / \mathrm{ml}$. Components $\mathrm{C} 3, \mathrm{C} 4$, and B were determined as described elsewhere and expressed as $\mu \mathrm{g} / \mathrm{ml}(30)$. Properdin (factor P) levels were determined by rocket electrophoresis with a rabbit antiserum specific for factor P; concentrations are expressed as $\mu \mathrm{g} / \mathrm{ml}$. Factor $\mathrm{D}$ was determined by functional titration as described elsewhere (30) and expressed as $\mathrm{U} / \mathrm{ml}$.

Granulocytes. Granulocytes were isolated from the blood of healthy adult donors by dextran sedimentation of the erythrocytes, as described elsewhere (31), and suspended in HBSS with $0.1 \%$ gelatin to a final concentration of $10^{7}$ cells $/ \mathrm{ml}$.

Microorganisms. S. aureus (type 42D), E. coli (054), and a 
clinical isolate of group B streptococci type III were cultured overnight at $37^{\circ} \mathrm{C}$ in Nutrient Broth (Oxoid Ltd, London, England), harvested by centrifugation at $1500 \times g$ for $10 \mathrm{~min}$, washed twice with phosphate buffered saline, and resuspended in gelatin to a concentration of approximately $10^{7}$ bacteria $/ \mathrm{ml}$. All bacteria were serum resistant, i.e. incubation of $5 \times 10^{6} \mathrm{bacteria} / \mathrm{ml}$ in 10 or $90 \%$ normal serum for $2 \mathrm{~h}$ at $37^{\circ} \mathrm{C}$ did not lead to detectable decrease in the number of viable bacteria.

Preopsonization of bacteria was performed by incubating $5 \times$ $10^{6} \mathrm{bacteria} / \mathrm{ml}$ with various concentrations of normal serum for $30 \mathrm{~min}$ at $37^{\circ} \mathrm{C}$ under slow rotation (4 rpm); next the suspension was cooled to $4^{\circ} \mathrm{C}$, and the excess serum removed by centrifugation and two washes with ice-cold HBSS. The bacteria were then resuspended in gelatin-HBSS to a concentration of $10^{7} / \mathrm{ml}$.

Determination of the opsonic activity of serum. The opsonic activity of a serum was determined as its capacity to promote ingestion of bacteria. This was measured by incubation of 100 $\mu \mathrm{l}$ of a suspension of granulocytes (concentration: $10^{7}$ cells $/ \mathrm{ml}$ ) with an equal volume of a suspension of $10^{7}$ bacteria $/ \mathrm{ml}$ in the presence of various concentrations serum at $37^{\circ} \mathrm{C}$ and $4 \mathrm{rpm}$. At 0,30 , and $60 \mathrm{~min}, 50-\mu \mathrm{l}$ aliquots of the mixture were added to $450 \mu 1$ ice-cold HBSS, after which the cells were pelleted by differential centrifugation for $6 \mathrm{~min}$ at $75 \times g$ and the number of the viable extracellular bacteria determined by a microbiological assay (32). In control experiments $200 \mu \mathrm{l}$ of a suspension of $5 \times 10^{6}$ bacteria/ml were incubated under rotation $(4 \mathrm{rpm})$ at $37^{\circ} \mathrm{C}$ with various concentrations $(\mathrm{v} / \mathrm{v})$ of the serum under study, and at various time-points the number of viable bacteria was determined microbiologically.

Since noningested bacteria proliferate during incubation of a suspension of granulocytes and bacteria, the number of viable extracellular bacteria must be corrected for this extracellular growth according to the formula (33): $\mathrm{NC}_{t}=\mathrm{N}_{t} \times \mathrm{B}_{0} / \mathrm{B}_{t}$, in which $\mathrm{NC}_{t}$ is the corrected number of extracellular bacteria at time $t, N_{t}$ the number of extracellular bacteria counted at time $t, B_{0}$ the initial number of bacteria in the suspension of only bacteria and serum, and $B_{t}$ the number of viable bacteria in this suspension at time t. After this correction, phagocytosis can be expressed as the percentage decrease in the corrected number of viable extracellular bacteria according to the formula:

$$
\mathrm{P}(\mathrm{t})=\left[\left(1-\mathrm{NC}_{\mathrm{t}}\right) / \mathrm{N}_{0}\right] \times 100
$$

in which $P(t)$ is the percentage phagocytosis at time $t$, and $N_{0}$ the number of viable extracellular bacteria at time $t=0$.

Data are expressed as mean and SD of at least three independent experiments. Statistical analysis was performed with Student's two-tailed $t$ test for unpaired observations.

\section{RESULTS}

Opsonic activity of cord blood serum. Incubation of $5 \times 10^{6} /$ $\mathrm{ml}$ granulocytes and $5 \times 10^{6} / \mathrm{ml} S$. aureus, E. coli, or group B streptococci in the presence of various concentrations of either cord blood or adult serum at $37^{\circ} \mathrm{C}$ for 60 min showed that phagocytosis of all of these microorganisms is dependent on the concentration of the serum in the medium employed (Figs. 13 ). Ingestion of $S$. aureus proved to be similar in the presence of corresponding concentrations of cord blood and adult sera (Fig. 1 ). Ingestion of $E$. coli was significantly reduced in the presence of all concentrations of cord blood serum as compared with adult serum (Fig. 2). For group B streptococci a slightly higher degree of ingestion was found in the presence of adult serum compared with cord blood serum (Fig. 3). Comparable results were obtained when the phagocytosis assay was performed for 120 min instead of $60 \mathrm{~min}$ (data not shown).

Similar results were obtained in phagocytosis experiments performed with bacteria preopsonized with various concentrations of cord blood or adult serum instead of the serum present during the phagocytosis assay (data not shown).

Opsonic activity of inactivated cord blood serum. To find out

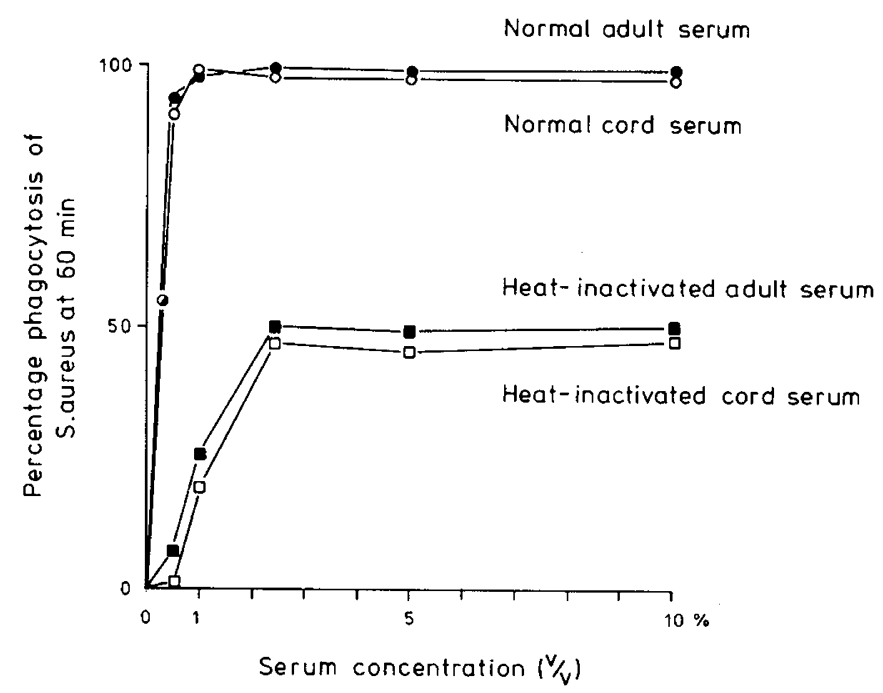

Fig. 1. Phagocytosis of $S$. aureus by granulocytes of healthy donors in the presence of the indicated concentrations of normal and heatinactivated cord and adult sera.

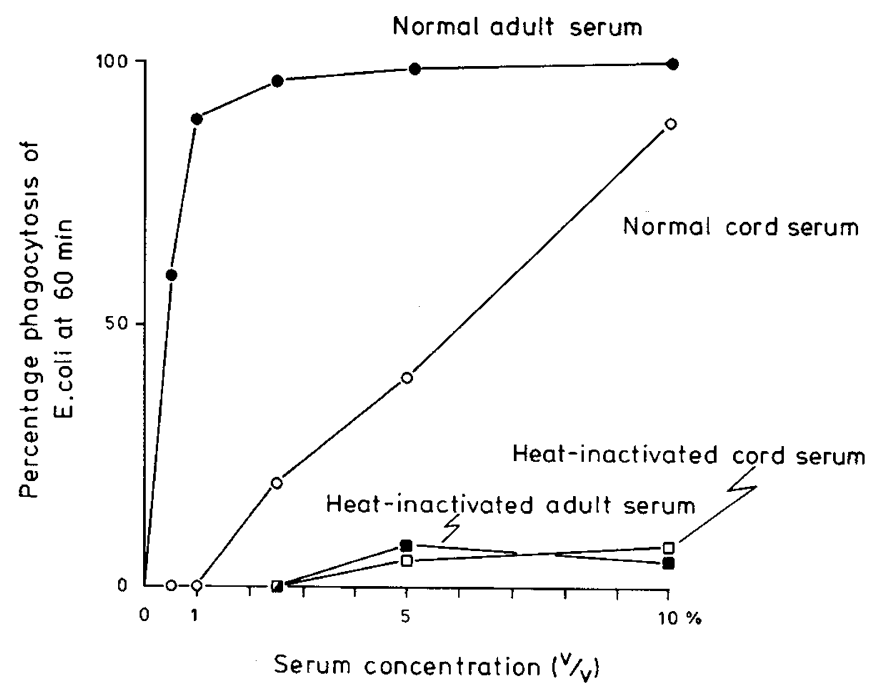

Fig. 2. Phagocytosis of $E$. coli by granulocytes of healthy donors in the presence of the indicated concentrations of normal and heat-inactivated cord and adult sera.

whether ingestion of microorganisms in the presence of cord blood serum is mediated mainly by heat-stable opsonins (IgG) or by heat-labile factors (complement components), the opsonic activity of heat-inactivated cord blood serum (i.e. IgG-mediated ingestion) was determined. Incubation of $5 \times 10^{6}$ granulocytes/ $\mathrm{ml}$ and $5 \times 10^{6} \mathrm{~S}$. aureus $/ \mathrm{ml}$ together with heat-inactivated cord blood serum in various concentrations induced ingestion to the same degree as did corresponding concentrations of heat-inactivated adult serum (Fig. 1). Similar incubation of granulocytes and $E$. coli resulted in almost complete abolition of ingestion of these bacteria in the presence of heat-inactivated serum, whether cord or adult serum was used (Fig. 2). For group B streptococci, phagocytosis in the presence of heat-inactivated cord blood serum was similar to that in the presence of heat-inactivated adult serum when the serum concentration amounted to 1.0 or more (Fig. 3).

Immunoglobulin and complement concentrations in cord blood serum. To find out whether the opsonic activity of cord blood serum is correlated with the concentration of the various opsonic proteins, i.e. immunoglobulins and complement components, 
the level of these proteins was determined in cord blood serum. The results show no detectable IgA in cord blood serum and an absent or lower concentration of IgM in cord blood than in adult serum (Table 1). No substantial differences were found between concentrations of $\mathrm{IgG}$ and $\mathrm{IgG}$ subclasses in cord blood and adult sera (Table 1).

Determination of the levels of complement components $\mathrm{C} 3$ and $\mathrm{C} 4$ and of factors $\mathrm{B}, \mathrm{P}$, and $\mathrm{D}$ in cord blood serum showed slightly lower concentrations of all five compared with those found in adult sera (Table 2). Investigation of complement activities of cord blood serum showed that although the capacity to activate the $\mathrm{CH} 50$ differed between the various sera, the mean CH50 activity was only slightly lower in cord than in adult sera. In all but one of the cord sera the level of at least one factor of the alternative pathway $(B, D$, or $P$ ) was lower than in sera from

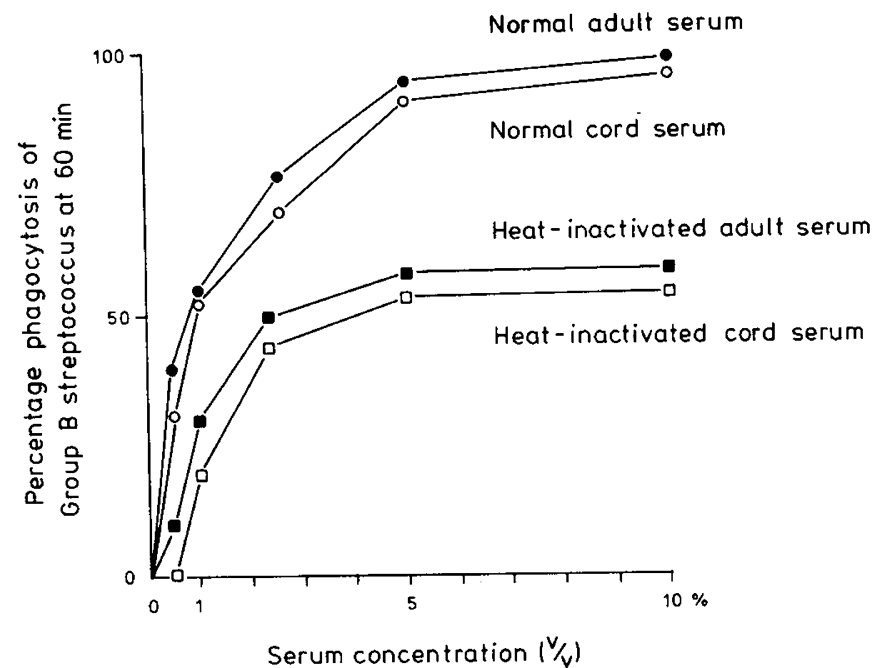

Fig. 3. Phagocytosis of group B streptococci by granulocytes of healthy donors in the presence of the indicated concentrations of normal and heat-inactivated cord and adult sera. adults, which explains why the ability to activate the AP50 was almost negligible in these sera (Table 2).

Complement activation by various microorganisms. To assess the capacity of the above mentioned microorganisms to activate the $\mathrm{CH} 50$ and AP50, $5 \times 10^{7}$ bacteria were incubated with $50 \%$ normal adult serum for $30 \mathrm{~min}$ at $37^{\circ} \mathrm{C}$. The suspension was then cooled to $4^{\circ} \mathrm{C}$, the bacteria removed by centrifugation at $1500 \times g$ for $10 \mathrm{~min}$, and the residual complement activity in the supernatant determined. The results showed a total loss of the classical pathway activity by $S$. aureus, E. coli, and group B streptococci (Table 3 ). With respect to the alternative pathway $S$. aureus induced $22 \%$ consumption of AP50 activity, while group B streptococci did not induce any consumption (Table 3 ). E. coli induced $100 \%$ consumption of AP50 activity (Table 3).

\section{DISCUSSION}

In the present study cord blood serum proved to be as active as serum from healthy adults for the opsonization of microorganisms by $\mathrm{IgG}$ and complement when the latter is activated via the $\mathrm{CH} 50$, which is the case for $S$. aureus and group B streptococci. Cord blood serum is inadequate for optimal opsonization when microorganisms, e.g. E. coli, activate the AP50 as well. The absence of activation of the AP50 by cord blood serum is in all probability due to a decreased level of at least one of the factors, B, P, and D of the AP50 in cord blood serum $(24,26)$.

Ingestion of $S$. aureus and group B streptococci in the presence of heat-inactivated adult serum and heat-inactivated cord blood

Table 3. Complement activation by various species of microorganism*

\begin{tabular}{lcc}
\hline \multicolumn{1}{c}{ Microorganism } & $\begin{array}{c}\text { Residual CH50 } \\
(\%)\end{array}$ & $\begin{array}{c}\text { Residual AP50 } \\
(\%)\end{array}$ \\
\hline S. aureus & 0 & 78 \\
E. coli & 0 & 0 \\
Group B streptococci & 0 & 100 \\
\hline
\end{tabular}

* Determinated after incubation of $5 \times 10^{7}$ microorganisms with $50 \%$ donor $\mathrm{AB}$ serum for $30 \mathrm{~min}$ at $37^{\circ} \mathrm{C}$.

Table 1. Levels of immunoglobulins in cord blood and adult sera

\begin{tabular}{cccccccc}
\hline \multirow{2}{*}{$\begin{array}{c}\text { Source of } \\
\text { Serum }\end{array}$} & \multicolumn{7}{c}{ Immunoglobulins } \\
\cline { 2 - 8 } & $\mathrm{IgA}^{*}$ & $\mathrm{IgM}^{*}$ & $\mathrm{IgG}^{*}$ & $\mathrm{IgG}_{1} \dagger$ & $\mathrm{IgG}_{2} \dagger$ & $\mathrm{IgG}_{3} \dagger$ & $\mathrm{IgG}_{4} \dagger$ \\
\hline $\begin{array}{c}\text { Cord blood } \\
\text { Mean }\end{array}$ & 0 & 4 & 110 & & & & \\
Median & 0 & 3 & 108 & $1 / 250$ & $1 / 64$ & $1 / 64$ & $1 / 8$ \\
Range & 0 & $0-11$ & $84-145$ & $1 / 64-1 / 500$ & $1 / 16-1 / 250$ & $1 / 16-1 / 64$ & $1 / 2-1 / 32$ \\
& & & & & & & \\
Adult blood & $50-270$ & $60-250$ & $80-220$ & $1 / 250$ & $1 / 64$ & $1 / 64$ & $1 / 8$ \\
$\quad$ Range & & & &
\end{tabular}

* Expressed as IU/ml.

$\dagger$ Expressed as maximal dilution giving precipitation.

Table 2. Complement activity and levels of complement components in cord blood and adult sera

\begin{tabular}{|c|c|c|c|c|c|c|c|}
\hline \multirow[b]{2}{*}{ Source of serum } & \multicolumn{2}{|c|}{ Complement activity } & \multicolumn{5}{|c|}{ Complement } \\
\hline & $\begin{array}{c}\text { CH50 } \\
(\mathrm{U} / \mathrm{ml})\end{array}$ & $\begin{array}{c}\text { AP50 } \\
(\mathrm{U} / \mathrm{ml})\end{array}$ & $\begin{array}{c}\mathrm{C} 3 \\
(\mu \mathrm{g} / \mathrm{ml})\end{array}$ & $\begin{array}{c}\mathrm{C} 4 \\
(\mu \mathrm{g} / \mathrm{ml})\end{array}$ & $\begin{array}{c}\text { B } \\
(\mu \mathrm{g} / \mathrm{ml})\end{array}$ & $\begin{array}{c}\mathbf{P} \\
(\mu \mathrm{g} / \mathrm{ml})\end{array}$ & $\begin{array}{c}\mathrm{D} \\
(\mathrm{U} / \mathrm{ml})\end{array}$ \\
\hline $\begin{array}{l}\text { Cord blood } \\
\text { Mean } \\
\text { Median } \\
\text { Range }\end{array}$ & $\begin{array}{l}183 \\
191 \\
0-374\end{array}$ & $\begin{array}{c}2 \\
2 \\
0-6\end{array}$ & $\begin{array}{c}700 \\
710 \\
490-830\end{array}$ & $\begin{array}{c}170 \\
160 \\
50-400\end{array}$ & $\begin{array}{c}80 \\
80 \\
40-180\end{array}$ & $\begin{array}{l}14.7 \\
14.3 \\
0-19\end{array}$ & $\begin{array}{c}43 \\
33 \\
0-100\end{array}$ \\
\hline $\begin{array}{l}\text { Adult blood } \\
\text { Range }\end{array}$ & $256-580$ & $8-24$ & $690-1040$ & $170-300$ & $130-220$ & $17-18$ & $25-105$ \\
\hline
\end{tabular}


serum indicates that in cord blood serum IgG, which is present in the same concentration as in adult serum, is functionally active. The higher level of ingestion of S. aureus and group B streptococci in the presence of cord blood and normal adult sera than in the presence of heat-inactivated sera indicates that opsonization is optimal when complement can be activated to opsonize these bacteria. Both of these species of bacteria can activate the classical pathway of complement only; the AP50 slightly or not at all. The absence of ingestion of $E$. coli in the presence of heat-inactivated cord blood and adult serum indicates that the ingestion of $E$. coli is mainly complement mediated. The decreased ingestion of $E$. coli in less than $10 \%$ cord blood serum compared to adult serum indicates that, although $E$. coli is able to activate both pathways of complement, ingestion of $E$. coli is mainly mediated by opsonization via the AP50.

IgM antibodies can play a role in the opsonization of $E$. coli by activating complement via the classical pathway, but cord blood serum does not contain IgM, because this immunoglobulin does not cross the placenta. Addition of IgM to cord blood serum did not suffice to obtain maximal phagocytosis of $E$. coli in vitro $(11,34)$.

Acknowledgments. The authors are grateful to Prof. J. Bennebroek-Gravenhorst and his staff of the Department of Obstetrics and Gynaecology of the Leiden University Hospital and to Dr. C. D. van der Does and his staff of the Department of Gynaecology of the Diaconessenhuis, Leiden, for supplying cord blood for the study. The authors are also grateful to Mrs. R. v. WeydenRagas, Department of Pediatrics of the Leiden University Hospital for performing the immunoglobulin determinations.

\section{REFERENCES}

1. Johnston RB, Klemperer MR, Alper CA 1969 The enhancement of bacterial phagocytosis by serum. The role of complement components and two cofactors. J Exp Med 129:1275-1290

2. Minta JO, Movat HZ 1979 The complement system and inflammation. In: Movat $\mathrm{H}$ (ed) Current Topics in Pathology. Inflammatory Reactions, Vol 68. Springer Verlag, New York, pp 135-178

3. Müller-Eberhard HJ, Schreiber RD 1980 Molecular biology and chemistry of the alternative pathway of complement. Adv Immunol 29:1-53

4. Ward PA, Cochrane CG, Müller-Eberhard HJ 1965 The role of serum complement in chemotaxis of leukocytes in vitro. J Exp Med 122:327-436

5. Hobbs JR, Miluer RD, Watt PJ 1967 Gamma-M deficiency predisposing to meningococcal septicaemia. Br Med J 4:583 586.

6. Oxelius VA 1974 Chronic infections in a family with hereditary deficiency of $\mathrm{IgG}_{2}$ and $\mathrm{IgG}_{4}$. Clin Exp Immunol 17:19-27

7. Snyderman R, Pike MC 1977 Disorders of leukocyte chemotaxis. Pediatr Clin North Am 24:377-393

8. Winkelstein JA, Drachman RH 1968 Deficiency of pneumococcal serum opsonizing activity in sickle cell disease. N Engl J Med 279:459-466

9. Cocchi P, Marianelli L 1967 Phagocytosis and intracellular killing of Pseudomonas aeruginosa in premature infants. Helv Paediatr Acta 22:110-118

10. Coen R, Grush O, Kauder E 1969 Studies of bactericidal activity and metabolism of the leukocyte in full-term neonates. J Pediatr 75:400-406

11. Dossett JH, Williams RC Jr, Quie PG 1969 Studies on interaction of bacteria, serum factors and polymorphonuclear leukocytes in mothers and newborns.
Pediatrics 44:49-57

12. Forman ML, Stiehm ER 1969 Impaired opsonic activity but normal phagocytosis in low-birth-weight infants. N Engl J Med 281:926-931

13. Graham CH, Saba TM, Lolekha S, Gotoff SP 1973 Deficient serum opsonic activity for macrophage function in newborn infants. Proc Soc Exp Biol Med 143:991-994

14. Kobayashi Y, Usui T 1982 Opsonic activity of cord serum-an evaluation based on determination of oxygen consumption by leukocytes. Pediatr Res $16: 243-250$

15. McCracken GH, Eichenwald HF 1971 Leukocyte function and the develop ment of opsonic and complement activity in the neonate. Am J Dis Child 121:120-126

16. Miyamoto K 1965 Phagocytic activity of the phagocytic activity of leukocytes between premature infants and full term infants. Hiroshima J Med Sci 14:9_ 17

17. Stossel TP, Alper CA, Rosen FS 1973 Opsonic activity in the newborn: Role of properdin. Pediatrics 52:134-137

18. Adamkin D, Stitzel A, Urmson J, Farness M, Posa E, Spitou R 1978 Activity of the alternative pathway of complement in the newborn infant. J Pediatr 93:604-608

19. Adinolfi M 1977 Human complement. Onset and site of synthesis during fetal life. Am J Dis Child 131:1015-1023

20. Davis CA, Vallota EH, Forristal J 1979 Serum complement levels in infancy: age related changes. Pediatr Res 13:1043-1046

21. Edwards MS, Buffone GJ, Fuselier PA, Weeks JL, Baker CJ 1983 Deficient classical complement pathway activity in newborn sera. Pediatr Res 17:685688

22. Johnston U, Truedsson L, Gustavii B 1983 Complement components in 100 newborns and their mothers determined by electroimmunoassay. Acta $\mathrm{Pa}$ thol Microbiol Scand [C] 91:147-150

23. Norman ME, Gall EP, Taylor A, Laster L, Nillson UR 1975 The complement profiles in infants and children. J Pediatr 87:912-916

24. Notarangelo LD, Chirico G, Chiara A, Colombo A, Rondini G, Plebani A, Martini A, Ugazio AG 1984 Activity of classical and alternative pathways of complement in preterm and small for gestational age infants. Pediatr Res 18:281-285

25. Sawyer MK, Forman ML, Kuplic LS, Stiehm ER 1971 Developmental aspects of the human complement system. Biol Neonate 19:148-162

26. Shapiro R, Beatty DW, Woods DL, Malan AF 1981 Serum complement and immunoglobulin values in small-for-gestational-age infants. J Pediatr 99:139-141

27. Winkelstein JA, Kurlandsky LE, Swift AJ 1979 Defective activation of the third component of complement in the sera of newborn infants. Pediatr Res 13:1093-1096

28. Ouchterlony Ö 1958 Diffusion-in-gel methods in immunological analysis. In: Kallos P (ed) Progress in Allergy, Vol V. Karger, Basel, pp 1-78

29. Daha MR, van Es LA 1981 Enhanced alternative complement pathwaydependent degradation of soluble immunoglobulin aggregates by macrophages. Immunology 43:513-518

30. Leijh PCJ, van den Barselaar MTh, van Zwet ThL, Daha MR, van Furth $R$ 1979 Requirement of extracellular complement and immunoglobulin for intracellular killing of micro-organisms by human monocytes. J Clin Invest 63:772-784

31. van Furth R, van Zwet ThL, Leijh PCJ 1978 In vitro determination of phagocytosis and intracellular killing in polymorphonuclear and mononuclear phagocytes. In: Weir DM (eds) Handbook of Experimental Immunology. Blackwell Scientific Publications, Oxford, pp 32.1-32.19

32. Maródi L, Leijh PCJ, van Furth R 1983 A micro-method for the separate evaluation of phagocytosis and intracellular killing of Staphylococcus aureus by human monocytes and granulocytes. J Immunol Methods 57:353-361

33. Leijh PCJ, van den Barselaar MTh, van Zwet TL Dubbeldeman-Rempt I, van Furth R 1980 Kinetics of phagocytosis and intracellular killing of Staphylococcus aureus and Escherichia coli by human monocytes. Scand J Immunol 13:159-174

34. Miller ME 1969 Phagocytosis in the newborn infant: humoral and cellular factors. J Pediatr 74:255-259 